\title{
Key Points of Fighting against Terrorism in the Northwest in the Future
}

\author{
Jianbo Wang, Haolin Cui, Jiangbin Dai \\ Air Control \& Navigation College, Air Force Engineering University, Xi'an, China \\ Jianbowang2008@163.com
}

Keywords: northwest direction; terrorist activities; fighting against terrorism; key points.

\begin{abstract}
Recent years, the terrorist activities represented by "East Turkistan” in the northwest have spread nationwide. Terrorist activities in the northwest show both common features and distinctive characteristics with international terrorist activities. It is of great significance to study the new trends and to identify the key points of the future struggle against terrorism in the northwest region, which is significant to the security, stability and development of the border areas.
\end{abstract}

\section{Introduction}

At present, international terrorism and extremism pose a serious threat to the world even the whole human civilization. Despite the fact that the international community has adopted various counter-terrorism measures and achieved initial results, the global anti-terrorism situation has not fundamentally improved; on the contrary, there has been a "the more the more anti-terrorism" situation in some areas. China, like many of the world's countries, is the victim of terrorism. For a long time, the terrorist forces represented by the "East Turkistan " in the northwest have created a series of terrorist activities at home and abroad, seriously endangering China's national security and social stability, and have also caused baneful influence and serious consequences in the international community ${ }^{[1]}$. identifying the key points of the future struggle against terrorism in the northwest region by analyzing various types of terrorist events implemented by "East Turkistan " statistically in recent years, summing up the distinctive characteristics of these terrorist activities will be of great importance to northwest border and even the whole country security and long-term development .

\section{Terrorist Activities and Characteristics Analysis}

"East Turkistan", also known as "East Turkistan Independence ", is the short of "East Turkistan Independence Movement", refers to national separatist movements domestic and overseas launched by separatists of national minority in Xinjiang Autonomous Region ,which attempt to separate Xinjiang from China by violent terrorist means and establish the so-called "East Turkestan country", and is a terrorist organization combined with terrorism, ethnic separatism and religious extremism Over the past 10 years, the "East Turkistan" terrorist organizations launched a series of terrorist attacks under the organization and planning of external terrorists, the more typical are:

March 7, 2008 , CSA6901 flight hijacking incident from Urumqi to Beijing;

July 5, 2009, seriously violent crime incident of smashing and burning in Urumqi;

July 8, 2011, terrorist incident in Hetian, Xinjiang;

February 28, 2012, terrorist attacks occurred in Yecheng, Kashi, Xinjiang;

June 26, 2013, terrorist attacks occurred in Shanshan, Xinjiang;

March 1, 2014,severely violent terrorist incident happened in Kunming Railway Station;

September 21, 2014, explosion attack took place in Luntai, Bazhou, Xinjiang;

July 13, 2015, terrorist attacks in Shenyang, Liaoning.

From the above terrorist attacks, we can sum up the following characteristics:

First, the age of terrorists tends to be juvenile. According to the data released by the Ministry of Public Security website statistics we can find that the third batch of terrorists age was significantly younger age, terrorists born in the 1980s accounted for 50\% of the total, while terrorists born in the 1970 s dropped to $33 \%$ and the data was only $17 \%$ in the 1960 s. The proportion of domestic "East 
Turkistan" terrorists have a regular change in age structure, reflecting the terrorist forces are tilting to the youth groups.

Second, the cultural structure of terrorists shows a low degree of education. Terrorists with junior and secondary education levels account for $78 \%$ of the total, while only $22 \%$ of terrorists with college, secondary and high school education.

Third, the domestic terrorist attacks concentrate on the south of Xinjiang. The uneven population distribution, the low educational level of ethnic minorities and the backward level of local economic development are breeding ground for terrorists.

Fourth, the time of the terrorist attacks shows regularity. Through the study of the time data of terrorist attacks in China, it is found that the high incidence of terrorist attacks is from 21:00 to the early hours and relatively concentrated on three rush hours at 6:00 to 9:00 (morning), 12:00 to 16:00 (noon), 17:00 to 18:00 (evening).

\section{New Trends in Terrorist Activities in the Northwest}

First, the objects of attack turn to civilians. the object of attack has transformed from the government agencies, violent organs to personnel-intensive places, important transport facilities and the vast number of innocent civilians, intending to create a wide range of social panic and international public pressure to threaten our government and thus to achieve its specific political and ideological purposes by "let more people die, but also let more people see".

Second, the means of attack turn to terrorism. The weapons which terrorists used have changed from machetes, axes, daggers, petrol bottles to simple explosive devices and guns, the means of attack have changed from slaughter, arson to slaughter, exploded, hijacked, hijacked hostages. Terrorists committed terrorist attacks by means of illegal manufacture of flammable and explosive materials, border smuggling of weapons and robbery of guns, reflecting the development of terrorist attacks in the direction of minimizing the use of weapons of mass destruction.

Third, the scope of the attack turns to expansion. The scope of the terrorist attacks has spread from Kashi ,Aksu ,Hetian in Xinjiang to other parts of the country, terrorism can take place from the border to the mainland, from the ground to the air, from the local to the overall ${ }^{[2]}$. Airports, railway stations and other important transport hubs have become the targets of terrorist attacks.

Fourth, terrorism and religious extremism are intertwined with each other. Terrorists confuse, deceive, and lure religious people by inciting religious frenzy, distorting the tampering of religious doctrines, fabricating all kinds of heresy that are under the banner of religion, associate religious extremism with minority dissatisfaction with reality and spread terror doctrine of ways to intensify social contradictions, brewing "lone wolf" or "family" terrorists. These terrorist organizations were closed and their actions were more subtle, so it is difficult to prevent effectively.

\section{Key Points of the Future Struggle Against Terrorism}

Make good use of data analysis.At present, modern information technology such as big data, cloud computing and Internet of Things has been widely used. The application of data analysis to anti-terrorism will show a more scientific, objective and convincing characteristics in intelligence analysis.First, found the internal links of terrorist organizations through the data analysis. Through the study of terrorist personal data, we can string various changes of the terrorist groups based on personal data together to form a panoramic view. Second, By analyzing the global terrorist attacks in recent years, we can predict the changes in the style of terrorist attacks. it can be seen from the choice of the scale, situation, target, event and place of the attack ${ }^{[3]}$. Third, we can grasp the development trends of terrorist attacks by quantify ing the causes and effects of all the terrorist attacks, analyzing the correlation data of the large data sets with the data model, exploring some explicit and intrinsic associations from the hidden terrorist attacks.

Preparing for a fight against terrorism.First, we must correctly grasp the anti-terrorism military struggle principles. we should focus on the following principles: a high degree of concentration about 
the organization and command; obey the overall situation about means to use; highlight the focus; retreat after win when action ${ }^{[4]}$. Second, establish and improve the anti-terrorism military struggle of the joint command system. Establish a practical and reliable mode of cooperation in accordance with the actual situation of anti-terrorism, understand the basic functions of the joint command agencies, improve the internal structure of the command agencies, and correctly handle the relationship between the usual and wartime.Third, organize and implement anti-terrorism military operations strictly. To strength of the diversification,high technological content, combat skills and strong forces must be deployed into the anti-terrorism power construction plan, we must attach importance to solve the key and difficult problems to ensure the implementation of unified management, unified plan, unified command.

Lay the people against the war of terror. First, We should fully mobilize the enthusiasm of the masses, create a common atmosphere and momentum of anti-terrorism to enhance the awareness of universal anti-terrorism and people's sense of mission and responsibility to resist the threat of terrorism .To mobilize the whole society, all-round, multi-level, planned to do a good job in counter-terrorism education. To enhance the people's political discernment, we should make the general public clear that terrorism "is neither a national issue, nor a religious issue, but a common enemy of all peoples." ${ }^{[5]}$ Second, we should enhance the people's ability to fight against terrorism. We must take the advantages of local technical equipment, information development and scientific and technological personnel in order to provide technical and equipment support for anti-terrorism. Third, we should establish a strong overall strategic system of institutional mechanisms. The anti-terrorism struggle should be referred to a strategic height,and a variety of anti-terrorism forces should clear their own jobs according to the national anti-terrorism leading group. we must establish and strengthen anti-terrorism mechanism of the party and government, and stick to the leadership of the party committee, government-led, military and police joint, military and civilian participation.

\section{Summary}

The struggle against terrorism in the northwest region is long-term complicated, and it is necessary to fully understand its characteristics, to accurately grasp its trends, to use anti-terrorism new technologies such as big data, to do a good job in the fight against terrorism.

\section{References}

[1]. Wang Yong, Mei Jianming. Hand in hand to build a global anti-terrorism strategy system.www.people.cn .2017.05.08

[2]. Guo Yongliang, Jiang Donglong. On China's strategic transformation of the fight against terrorism, the Chinese People's Public Security University (Social Science Edition), 2016.5

[3]. Sun Yu, Deng Bo. Data perspective of the terrorist attacks intelligence analysis. Journal of PLA University of Science and Technology (Military Science Edition) .2015.12

[4]. Zhu Jinlin. Grasp the anti-terrorism and anti-terrorism military struggle of the joint. Military academics, 2003 (1)

[5]. Guo Yongliang. On the anti-terrorist war. China Military Science .2017 (1) 